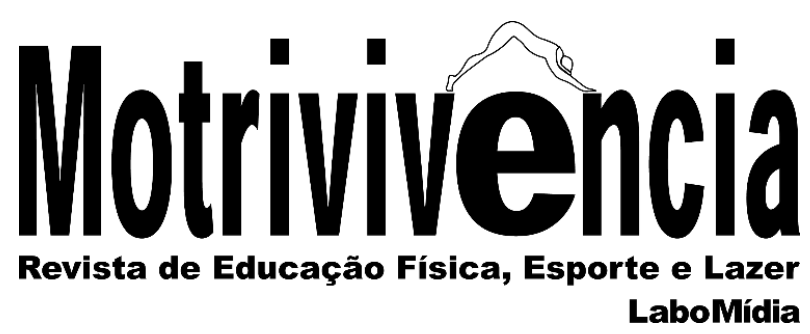

\title{
Política nacional do esporte: as consequências do desmonte do ministério do esporte
}

\section{RESUMO}

O texto trata de demonstrar com dados empíricos a Política Nacional de Esporte, desenvolvida nos Governos de Luís Inácio Lula da Silva e Dilma Rousseff (2003-2016) e, as consequências do desmonte do Ministério do Esporte, da interrupção das ações desenvolvidas, relacionando à política do desmonte das instituições democráticas no Brasil, com a alegação do ajuste fiscal e, com a destruição de forças produtivas materiais, pela privação da classe trabalhadora ao patrimônio cultural.

PALAVRAS-CHAVE: Política nacional do esporte; Ministério do esporte; Cultura corporal; Esporte
Celi Nelza Zulke Taffarel

Doutora em Educação Universidade Federal da Bahia - UFBA

FACED, Departamento III Salvador, Bahia, Brasil celi.taffarel@gmail.com https://orcid.org/0000-0003-3593-4279

Claudio de Lira Santos Junior Doutor em Educação Universidade Federal da Bahia - UFBA

FACED, Departamento III Salvador, Bahia, Brasil clirasj@gmail.com

https://orcid.org/0000-0001-7172-1823 


\title{
National sport policy: the consequences of dismantling the ministry of sport
}

\begin{abstract}
The text tries to demonstrate with empirical data the National Sports Policy, developed in the Governments of Luís Inácio Lula da Silva and Dilma Rousseff (2003-2016) and, the consequences of the dismantling of the Ministry of Sports, of the interruption of the developed actions, relating the politic of dismantling with the allegation of fiscal adjustment and, with the destruction of material productive forces, the deprivation of the working class to the cultural patrimony.
\end{abstract}

KEYWORDS: National sports politics; Sport ministery; Body culture; Sport

Política deportiva nacional: las consecuencias del desmantelamiento del ministerio del deporte

\section{RESUMEN}

El texto trata de demonstrar com datos empíricos la Política Nacional de Deporte, desarrollada em los Gobiernos de Luís Inácio Lula da Silva Y Dilma Rousseff (2003-2016) y, las consecuencias del desmonte del Ministerio del Deporte, de la interrupción de las acciones desarrolhadas, politica del desmonte de las instituiciónes democraticas del Brasil, com la alegación del ajuste fiscal y, com la destrzcción de fueras produtivas materiales, por la privación de la classe trabajadora al patrimônio cultural.

PALABRAS-CLAVE: Política nacional del deporte; Ministerio del deporte; Cultura corporal; Desporte 


\section{INTRODUÇÃO}

[...] En una sociedad de clases como es el capitalista, cualquier medida de política económica provoca damnificados, y em mayor medida cuanto se trata de medidas muy agresivas como son las políticas de ajuste permanente del FMI. [...] las grandes contrarreformas que constituyen el núcleo duro del ajuste [...] a) las privatizaciones de empresas e servicios públicos; b) la desregulación de las relaciones de explotación que vinculan a capital y trabajo, [...] c) la apertura que supone la desregulación externa, tanto comercial e financeira llevada a cabo de una forma acelerada, indiscriminada y sin control estatal alguno. Todas las cuales tienen consecuencias graves em matéria no sólo económica y social, sino también política, en el sentido de que cuestionan la democracia y su base ineludible em la economia capitalista: la soberania nacional. [...] su funcion [...] abrir espacios de rentabilidade para la acumulacion [...] Privatizaciones: busqueda de nuevos espacios de acumulácion, descenso del salario indirecto y destrucción de forzas produtivas (MONTORO; 2014, pp. 388-389)

Trataremos no presente texto da Política do Esporte durante os governos de Luís Inácio Lula da Silva, em seus dois mandatos (2003-2010) e Dilma Rousseff em seu primeiro mandato (20112014) e no inconcluso segundo mandato (2015-2016) levando em consideração uma base conceitual e histórica para reconhecer, pelos fatos, consequências do desmonte do Ministério do Esporte e da destruição das políticas esportivas e, o que fazer em tempos de avanços da barbárie.

O texto apresenta contribuições para responder a três indagações: (1) existem relações entre o desmonte do Ministério do Esporte, instalado em 2004, durante o primeiro governo de Luís Inácio Lula da Silva, para desenvolver políticas de universalização e democratização do Esporte, com a política econômica de aplicação de um violento ajuste fiscal, com suas medidas de privatização, desregulamentação, abertura externa indiscriminada para as grandes multinacionais, e seus resultados imediatos, a saber, destruição econômica, regressão social e questionamentos da democracia? (2) quais os nexos de tais medidas com a destruição de forças produtivas? Por fim: (3) por que é necessário a extrema direita destruir as políticas do Esporte construídas durante os Governos de Luís Inácio Lula da Silva (2003-2010) e Dilma Rousseff (2011-2016) e o que fazer diante da barbárie instalada?

Conceitualmente o Esporte é um elemento constitutivo da Cultura Corporal (TAFFAREL, 2010) que, em sua formulação mais avançada, mais desenvolvida, enquanto síntese da produção humana, tem suas origens na atividade para manutenção da vida, portanto, no trabalho, desde a sociedade comunal. É constituída de múltiplas experiências ideológicas, políticas, filosóficas e sociais e, por sentidos lúdico, estético, artístico, agonístico, competitivos ou outros, relacionados à realidade, às necessidades e motivações do ser humano em determinados modos de produção e reprodução da vida. Assim, faz-se evidente que estamos tratando de um objeto relacionado aos 
fenômenos das práticas cuja conexão geral ou primigênia - essência do objeto e o nexo interno das suas propriedades - determinante do seu conteúdo e estrutura de totalidade -, é dada pela materialização em forma de atividades, sejam criativas ou imitativas, das relações múltiplas de experiências subordinadas às leis histórico-sociais. O geral dessas atividades é que são valorizadas em si mesmas; seu produto não material é inseparável do ato da produção e; recebe um valor de uso particular por atender aos seus sentidos lúdicos, estéticos, artísticos, agonísticos, competitivos e outros relacionados à realidade e às motivações humanas. Elas se realizam com modelos socialmente elaborados que são portadores de significados, ideias do mundo objetal, das suas propriedades, nexos e relações descobertos pela prática social conjunta. Os conhecimentos, socialmente construídos e historicamente determinados, a partir de atividades que materializam as relações sociais, com sentidos e significados, são necessidades vitais (TEIXEIRA, DIAS; 2011, pp. 94-110), para o desenvolvimento dos seres humanos, para a formação de uma consciência necessária para a sua atuação no mundo, na direção da transformação radical da sociedade. Neste sentido reconhecemos o Esporte como um direito individual de todos e, portanto, também, como direito social.

Nos basta aqui e agora demonstrar, portanto, que a Política de Esporte tem um marco histórico, temporal, que o situa dentro do campo das reivindicações da classe trabalhadora, como direito individual e social, no marco do modo de produção capitalista, em sua fase imperialista (LENIN; 2007; 2010). Nos basta demonstrar que o Esporte está contemplado no Artigo 217 da Constituição Brasileira como direito individual ${ }^{1}$.

\footnotetext{
${ }^{1}$ Constituição Federal de 1988

Nós, representantes do povo brasileiro, reunidos em Assembléia Nacional Constituinte para instituir um Estado Democrático, destinado a assegurar o exercício dos direitos sociais e individuais, a liberdade, a segurança, o bem-estar, o desenvolvimento, a igualdade e a justiça como valores supremos de uma sociedade fraterna, pluralista e sem preconceitos, fundada na harmonia social e comprometida, na ordem interna e internacional, com a solução pacífica das controvérsias, promulgamos, sob a proteção de Deus, a seguinte CONSTITUIÇÃO DA REPÚBLICA FEDERATIVA DO BRASIL.

Art. 217. É dever do Estado fomentar práticas desportivas formais e não-formais, como direito de cada um, observados: I - a autonomia das entidades desportivas dirigentes e associações, quanto a sua organização e funcionamento;

II - a destinação de recursos públicos para a promoção prioritária do desporto educacional e, em casos específicos, para a do desporto de alto rendimento;

III - o tratamento diferenciado para o desporto profissional e o não- profissional;

IV - a proteção e o incentivo às manifestações desportivas de criação nacional.

$\S \mathbf{1}^{\mathbf{0}} \mathrm{O}$ Poder Judiciário só admitirá ações relativas à disciplina e às competições desportivas após esgotarem-se as instâncias da justiça desportiva, regulada em lei.

§ $2^{\mathbf{0}}$ A justiça desportiva terá o prazo máximo de sessenta dias, contados da instauração do processo, para proferir decisão final.

$\S 3^{\circ}$ O Poder Público incentivará o lazer, como forma de promoção social.
} 
O marco temporal para tratar das políticas do Esporte aqui assumido é, inicialmente, a origem e estrutura do sistema de proteção ao trabalho e ao trabalhador no Brasil e, suas respectivas leis que são fruto da reivindicação e da organização do movimento operário nos processos que se seguiram aos primórdios da industrialização e remontam ao final do século XIX e início de século XX (CASTIONI, 2008).

Foram as reivindicações dos trabalhadores, em especial a greve geral de 1917, que evidenciaram a necessidade de políticas públicas de proteção social e temos aí, refletindo a criação da Organização Internacional do Trabalho (OIT), em 1919, o constitucionalismo social caracterizado pela incorporação dos direitos sociais nas constituições. Em 1926, no Brasil, a emenda à Constituição de 1891, permitiu ao Congresso legislar sobre férias, acidentes de trabalho e, o código de menores. Em 1932 a Carteira de Trabalho e a Previdência Social tornam-se documento obrigatório. Estabelece-se a Lei das Convenções Coletivas e o estabelecimento das oito horas para o trabalho diurno e sete para o noturno. É deste período a instituição do Decreto-Lei 3.119 de 1941, que demarcou a intervenção do Estado no esporte brasileiro. Foi formalizada neste decreto primeira estrutura organizacional do esporte, hierárquica, fechada e fragmentada. Mas é somente em 1 de maio de 1943, através do Decreto Lei 5.452 assinado pelo presidente Getúlio Vargas, que entraria em vigor a CLT - Consolidação das Leis do Trabalho, que unificou em seus 11 títulos e 922 artigos, toda as normas que organizam o trabalho, os sindicatos, a Justiça do Trabalho e, o Sistema da Previdência Social.

Segundo Priscila Blank, Vinicius Rosa Ganzer e Luiz Fernando Veronez, no trabalho acadêmico sobre "O Método de Gestão do Ministério do Esporte” (2013, p. 01),

(...) a história institucional do esporte brasileiro teve início no ano de 1937, quando, por intermédio da Lei n ${ }^{\circ} 378$ de 13/03/37, foi criada a Divisão de Educação Física do Ministério da Educação e Cultura (DEF/MEC). Em 1970, com a difusão da Educação Física e do Desporto, por intermédio do Decreto No 66.967 de 27 de julho de 1970, a Divisão foi transformada em Departamento de Educação Física e Desportos do Ministério da Educação e Cultura (DED/MEC). Na sequência, em 1978, ocorre a transformação deste departamento em Secretaria de Educação Física e Desportos do Ministério da Educação e Cultura (SEED/MEC), que permaneceu atuando até 1989, ainda ligado ao Ministério da Educação. Em janeiro de 1990, durante o governo do então presidente Fernando Collor de Melo, a SEED/MEC é extinta e sede lugar a Secretaria de Desportos da Presidência da República. Após o impeachment do presidente Collor em 1992, o esporte voltou a ser vinculado ao Ministério da Educação, perdendo o vínculo com a Presidência da República, com a Secretaria de Desportos. A partir de 1995, o esporte começa a ser mais priorizado, com a posse do Presidente Fernando Henrique Cardoso, foi criado o Ministério de Estado Extraordinário do Esporte, sendo nomeado o ex-jogador de futebol Edson Arantes do Nascimento - Pelé (1995 a 1998) e cabendo à Secretaria de Desportos do Ministério da Educação, prestar o apoio técnico e administrativo. 
Em março do mesmo ano, esta secretaria é transformada no INDESP - Instituto Nacional de Desenvolvimento do Desporto, desvinculado do MEC e subordinado ao Ministério Extraordinário do Esporte. Em 31 de dezembro de 1998, durante o segundo mandato do Presidente Fernando Henrique Cardoso foi criado o Ministério do Esporte e Turismo, pela Medida Provisória $n^{\circ}$ 1.794-8 e o INDESP passa a ser vinculado a este órgão. Em outubro de 2000, o INDESP é extinto e em seu lugar é criada a Secretaria Nacional de Esporte (SNE), na estrutura do Ministério do Esporte e Turismo. Finalmente, em janeiro de 2003, no primeiro mandato do presidente Luís Inácio Lula da Silva e criado o Ministério do Esporte. (VERONEZ; GANZER; BLANK, 2013, p.01)

Estamos em pleno século XXI e, para responder a crise de acumulação do capital, resultante de contradições próprias ao sistema capitalista, desmontam-se instituições, que garantem acesso indireto a recursos públicos, na forma de garantias de direitos, rebaixam-se as Leis que protegem o trabalho e o trabalhador para garantir lucros aos capitalistas, mesmo que isto signifique a destruição de forças produtivas. A reforma Trabalhista, Lei 13.467/2017, que retirou direitos e conquistas, foi aprovada na Câmara Federal com 296 votos favoráveis e 177 contra, no senado com 50 votos favoráveis e 26 contras e, sancionada pelo então presidente golpista, Michel Temer, em 13 de julho de 2017. A Reforma da Previdência está tramitando no parlamento brasileiro e foi encaminhado, em 20 de fevereiro de 2019, pelo atual presidente da república, ex-campeão do exército brasileiro, Jair Bolsonaro, que ganhou as eleições de maneira fraudulenta em 2018, conforme demonstram fatos apresentados pela imprensa, em especial The Intercep e já denunciados anteriormente conforme demonstra Giovanaz (2018) em sua obra “ Dossiê Lava Jato: Um ano de cobertura crítica”. O processo da Contrarreforma da Previdência, neste momento, julho de 2019, encontra-se tramitando no Parlamento e, se aprovada, contribuirá profundamente para a desconstrução, retirada, perda, de direitos sociais (RAMOS ET ALLI, 2017). A proposta de Emenda Constitucional modifica o sistema de previdência social, estabelece regras de transição e disposições transitórias, e da outra providencias entre as quais destacamos o Regime de Capitalização. É uma proposta que segundo todas as centrais sindicais, penaliza os pobres para dar lucros aos banqueiros, ao setor rentista da economia.

Segundo os editores do "Dossiê: Governo Bolsonaro", editado pela Boitempo, na Revista Margem Esquerda, n. 32 de 1 de setembro, 2019, "O Brasil vive o governo mais obscurantista, regressivo, autoritário, antipopular e antinacional desde a ditadura militar implantada em 1964, na qual se inspira".

Iniciamos com estas referências porque não tem como tratar do Esporte, nem como direito individual ou social, como política pública, se não tivermos uma classe trabalhadora socialmente protegida e um mundo do trabalho protegido da ganância irracional do capital que destrói forças 
produtivas. Segundo Marx e Engels (2007, pp. 33-34) “ devemos começar a constatar o primeiro pressuposto de toda a existência humana e também, portanto, de toda a história, a saber, o pressuposto de que os homens têm de estar em condições de viver para poder fazer história". E prosseguem os autores, demonstrando que o primeiro ato histórico é a produção de meios para satisfazer as necessidades para garantir a vida, condição fundamentais para a existência. Ao longo da história da humanidade foram desenvolvidas forças produtivas, que significam o trabalho humano, na relação com a natureza, valendo-se de instrumentos e conhecimentos científicos e tecnológicos, para produzir os bens que garantem a existência e, que entram em relações sociais de produção e troca. Estas forças produtivas estão em franca destruição, pela ação de forças destrutivas (setor rentista da economia, agencia financiadoras internacionais, Banco Mundial, FMI, entre outras) que aplicam medidas como os ajustes estruturais, ou ajustes fiscais, impondo as nações, a destruição da natureza, dos direitos e conquistas, do Estado de Direito, da democracia, enfim, da soberania nacional. O exemplo no Brasil é a Emenda Constitucional 95/2016² que impõe um ajuste físcal que limita investimentos em políticas públicas de Estado e de Governo por 20 anos. As forças produtivas materiais, que é a capacidade de trabalho, constituem, com as relações de produção o real de um dado modo de produção para satisfazer necessidades sociais da vida e aqui no Brasil, elas estão ameaçadas de destruição. No modo de produção capitalista, são proteção e sem politicas sociais, as forças produtivas são exploradas para garantir a mais-valia, o excedente, o lucro, a concentração de riquezas, a propriedade privada do que é socialmente produzido.

Segundo Montoro $(2014$, p. 83)

O capitalismo não é um modo de produção programado; ele obedece aos interesses particulares de todos aqueles que realizam a acumulação, que são os capitais individuais. Em consequência, a expansão da acumulação, se deve à concorrência intercapitalista, à busca de rentabilidade de cada capital, o que confirma o caráter anacrônico do capitalismo que se verifica sob todos os terrenos e, particularmente, sob aquele da destruição das forças produtivas (MONTORO, 2014, p. 83).

Os trabalhadores precisam estar vivos e bem, para inclusive pensar em acessar o esporte, seja como meio de vida, seja como conhecimento elaborado culturalmente, seja como patrimônio social da humanidade, para qualquer finalidade. Mas isto, sob regimes de extrema direita, está se tornando cada vez mais difícil.

Montoro (2014; 2018) afirma ainda que, o resultado imediato dos ajustes estruturais, ajustes físcais são: destruição econômica, regressão social e questionamento da democracia. É isto que

2 Ver em https://www2.camara.leg.br/legin/fed/emecon/2016/emendaconstitucional-95-15-dezembro-2016-784029publicacaooriginal-151558-pl.html 
ocorre neste momento histórico no Brasil. Os índices de desemprego, a reforma trabalhista que retira direitos, os altos índices de violência em especial contra as mulheres, negros, pobres, LGBT, índios, imigrantes e, a prisão arbitrária do ex-presidente Luís Inácio Lula da Silva são evidências destes processos. E a isto estamos sujeitos enquanto produtores do conhecimento científico, formadores de professores e, profissionais que têm como objeto de seu trabalho a cultura corporal, e que atuam cientificamente em campos de trabalho que ora se expandem e ora se retraem, por determinações da economia política. Campos estes que mantêm uma regularidade: em todos, seja no sistema educacional, saúde, esportivo de alto rendimento, políticas públicas, privado ou público: sempre teremos alguém que ensina, algo a ensinar, com determinados métodos, em determinados espaços educativos, com determinadas finalidades e tempos pedagógicos, a destinatários que buscam satisfazer suas necessidades de apropriação da cultura corporal, lhe atribuindo sentidos e significados. A tríade conteúdo-método-destinatário (MARTINS, 2018) está presente em todos os espaços de atuação profissional de quem trata da cultura corporal. Campos de trabalho que encontram mais um obstáculo representado por um organismo de Estado que exerce força, inclusive policial, para regulamentar e controlar mercado de trabalho. Estamos nos referindo a atuação do CREF/CONFEF (DIAS JUNIOR; LIMA, 2012)

Entre as forças destrutivas, segundo Montoro (2014), estão os mecanismos gerados pela lógica do capital de subsumir o trabalho ao capital, o trabalho assalariado, intermitente, precarizado, terceirizado, a servidão voluntária (ANTUNES, 2018), e manter taxas de lucros, a apropriação privada, a concentração de rendas e riquezas, o assalto ao patrimônio público, ao Produto Interno Bruto por via de endividamento impagável ${ }^{3}$, as reformas e retirada de conquistas e direitos ${ }^{4}$. A não viabilidade de políticas sociais que garantam direitos e salários indiretos. Estes são os mecanismos para destruir o Sistema de Proteção do Trabalho e do Trabalhador (CASTIONI, 2008). Tais mecanismos podem ser identificados desde a produção social e apropriação privada, pela exploração da mais-valia relativa e absoluta, até os mecanismos do setor rentista que, para manter as taxas de lucro, provoca guerras híbridas, golpes, destrói democracias (KORYBKO, 2018), rasga constituições, retira direitos e conquistas dos trabalhadores e, destrói instituições democráticas (VALIM, 2017) e, políticas públicas de inclusão, democratização e universalização do acesso ao patrimônio cultural da humanidade.

Estes mecanismos contam com sofisticadíssimos aparelhos ideológicos e de ação política. A dominação burguesa não se mantém somente por herança política das classes dominantes. Casimiro (2018) apresenta dados estarrecedores sobre a atuação da velha, da nova direita e da extrema-direita

\footnotetext{
${ }^{3}$ Ver em https://auditoriacidada.org.br

${ }^{4}$ Ver em $\underline{\text { http://cedoc.cut.org.br/banco-de-teses }}$
} 
para assegurar a dominação econômica através da política e da gestão de formas de sociabilidade da classe trabalhadora. Estes grupos atuam tanto no sentido doutrinário, difundindo o pensamento de matriz liberal e, até fascista, recrutando intelectuais orgânicos, com a utilização de "think tanks" de direita que são instituições que produzem e difundem informações influenciando ideias na sociedade e decisões políticas a favor dos interesses do capital ${ }^{5}$, quanto no campo pragmático de elaboração de diretrizes, políticas públicas e de ação estrutural, desenvolvendo estratégias por fora e por dentro do Estado. Trata-se de um projeto de estruturação de dominação no conjunto da luta de classes, inclusive em formas de internacionalização no plano capital-imperialista.

Isto está evidente no governo que assumiu em 2019 no Brasil, com seus três núcleos de direita e extrema-direita no poder, a saber: 1) Núcleo que gerencia as políticas sociais (fundamentalistas, pentecostais, neopentecostais, empresários, privatistas); 2) Núcleo que gerencia a política econômica e o judiciário (economistas e judiciário partidarizado); 3) Núcleo que gerencia com medidas de exceção, autoritárias, antidemocráticas, a segurança e a ordem (militares e judiciário). Estes núcleos contam, por um lado, com a cumplicidade e os perigosos interesses geopolíticos do império Norte Americano na América Latina, em especial no Brasil (BANDEIRA, 1998; 2004), com o poder de uma mídia golpista, concentrada em seis famílias, com um empresariado entreguista, com latifundiários e milicianos. Dominam, retiram direitos e concentram riquezas, garantem lucros às custas de enormes sacrifícios da Classe Trabalhadora (DOSSIÊ: GOVERNO BOLSONARO, 2019).

Iniciamos, portanto, com estas referências porque a partir de 2003 com a eleição de Luís Inácio Lula da Silva, com todas as críticas e autocriticas, pertinentes, e que estão sendo realizadas conciliação de classe, adaptação ao aparelho estatal burguês, não realização de reformas vitais aos trabalhadores, descolamento da base social, não investimento na elevação da consciência de classe , alteraram-se correlações de forças e, em meio a grandes disputas, adotou-se uma nova estratégia de proteção social baseada no desenvolvimento econômico com estabilidade, distribuição de renda e convergência entre as ações universais e focalizadas (TEIXEIRA, 2015, p. 218). Mesmo as políticas focais, compensatórias, assistencialistas, de um modelo econômico neodesenvolvimentista, foram disputadas, palmo-a-palmo, com forças burguesas instaladas no interior do aparato Estatal para inviabilizarem qualquer benefício a classe trabalhadora.

O Golpe no Brasil (RAMOS et ali, 2017) não se resume a um fato único, destituição de uma presidenta legitimamente eleita por 54 milhões de votos, mas, paulatinamente, foi se aprofundando e demonstrando a sua face oculta. Desde a posse do presidente Luiz Inácio Lula da Silva em 2003,

${ }^{5}$ Link para matéria: https://www.nexojornal.com.br/expresso/2017/12/01/O-que-s\%C3\%A3o-think-tanks.-E-como-elesinfluenciam-a-pol\% $\overline{\mathrm{C} 3 \% \mathrm{ADtica}}$ 
passando pela Ação Penal 470, que inicia uma saga de perseguições e punições injustas desde 2004; a descoberta do Pré-sal em 2007 e seu volume de 50 bilhões de barris, passando pela eleição de Dilma Rousseff em 2014, para um segundo mandato, a sua destituição em 2016, às medidas adotadas pelo Governo de Michel Temer, até a prisão do ex-presidente Luís Inácio Lula da Silva, sem provas e sem lhe garantirem direitos previstos em lei, para afastá-lo do pleito eleitoral de 2018, até a designação de um Juiz de primeira instância à Ministro do Supremo Tribunal Federal para o mandato de 2019 a 2022, com superpoderes, bem como, a contrarreforma da previdência, à extinção do Ministério do Esporte (DAMIANI, 2018), entre outros, são sucessivas medidas adotadas ou anunciadas, com a finalidade de consolidar no Brasil, um regime de extrema-direita, que aprofunda a sustentação dos interesses do capital, por taxas de lucros exorbitantes, por riquezas concentradas, explorando e destruindo o patrimônio público, explorando ao máximo a mais-valia absoluta e relativa, gerada pelos trabalhadores super-explorados em trabalhos precarizados, flexibilizados, sem direitos trabalhistas, em regime de servidão voluntária (ANTUNES, 2018). São fatos que se interrelacionam com uma escolha política determinada por interesses financeiros e rentistas, que estão assegurando o êxito da reestruturação estatal defendida por forças destrutivas que estão impondo retrocessos inadmissíveis ao processo de desenvolvimento humano e social.

Neste contexto foi e está sendo disputada o rumo da Política em geral e em especial, a Política Nacional do Esporte.

\section{A POLITICA NACIONAL DO ESPORTE NO PERIODO DE 2003-2016: As críticas necessárias.}

O Esporte, ou como designa Castellani (1988, p. 11), a "Educação Física tem sido utilizada politicamente como uma arma a serviço de projetos que nem sempre apontam na direção das conquistas". Exemplo disto é a utilização do esporte, em pleno período da ditadura militar (ARNS, 1985) ${ }^{6}$, para alienar e afastar a juventude de suas organizações revolucionarias (ADUSP; 2004). Nas décadas de 1980 e 1990, em pleno período de aplicação dos acordos e Consenso de Washington (TOMMASI; WARDE; HADDAD; 1996) que visavam ajustar as macroeconomias de países em dificuldades aos interesses imperialistas, vemos o Esporte sendo utilizado para fins políticos de alienação da classe trabalhadora, principalmente com megaeventos futebolísticos.

Chegamos aos anos 2000, com a contraditória conciliação de classes, onde, por sua vez, as reivindicações dos trabalhadores são pautadas por políticas de Estado durante os governos de Luís Inácio Lula da Silva e Dilma Rousseff. As políticas de Estado foram instituídas neste período para

\footnotetext{
${ }^{6}$ Ver sobre em https://www.esquerda.net/dossier/50-anos-do-golpe-militar-no-brasil/31903
} 
terem um caráter mais permanente, sistêmico, com abrangência nacional. No período aqui tratado defendiam a democratização, universalização do esporte para todos. Já as políticas de governo constituíram-se de medidas conjunturais para responder a desafios do momento. $\mathrm{O}$ exemplo da política de Estado foi a criação do Ministério do Esporte (ME), através do Decreto Lei n. 10.683, de 2003, com a missão de construir uma Política Nacional de Esporte, para desenvolver esporte de alto rendimento, executar ações de inclusão social por meio do esporte e garantir à população brasileira o acesso gratuito à prática esportiva, com vistas à qualidade de vida e ao desenvolvimento humano. Foi necessário enfrentar grandes desafios para consolidar o setor. Era necessário construir a Política Nacional do Esporte (BRASIL, 2005), as políticas setoriais, seus programas e ações; ampliar e diversificar o financiamento do esporte; aprimorar o marco legal; estruturar a gestão do esporte sob mecanismos democráticos de participação e controle social (VERONEZ, 2013). E neste sentido são implementam programas, projetos e ações de relevância social, de inclusão, democratização e universalização do Esporte.

O trabalho acadêmico de Priscila Blank, Vinicius Rosa Ganzer e Luiz Fernando Camargo Veronez, publicado em Buenos Aires, em 2013, expos o método de gestão do Ministério do Esporte durante os governos de Luís Inácio Lula da Silva e Dilma Rousseff. Em 2003, demonstra que com a posse do Presidente Luiz Inácio Lula da Silva, o Ministério do Esporte e Turismo foi transformado em Ministério do Esporte com a missão de construir uma Política Nacional de Esporte que além de desenvolver o esporte de alto rendimento, trabalhasse com ações de inclusão social por meio do esporte, garantindo à população brasileira o acesso gratuito à prática esportiva, qualidade de vida e desenvolvimento humano. O ME passou a apresentar um modelo gestor dividido em várias partes, apresentando um grande número de secretarias e gabinetes, articulados entre si, a fim de gerir especificamente, diferentes áreas de atuação do ME.

A partir da reestruturação ocorrida na Estrutura Organizacional Federal, através da A Lei $n^{\circ}$ 10.683, de 28 de maio de 2003 que reestruturou a Estrutura Organizacional Federal permitiu no ME a criação de três Secretarias Nacionais: (1) a Secretaria Nacional de Desenvolvimento de Esporte e Lazer; (2) Secretaria Nacional de Esporte Educacional e; (3) a Secretaria Nacional de Esporte de Alto Rendimento.

Ainda segundo o estudo de Priscila Blank, Vinicius Rosa Ganzer e Luiz Fernando Camargo Veronez,

(...) conforme o decreto $\mathrm{N}^{\mathrm{o}} 7.784$, de 7 de agosto de 2012, foi aprovada a Estrutura Regimental e o Quadro Demonstrativo dos Cargos em Comissão e das Funções Gratificadas do Ministério do Esporte, ficando com a seguinte estrutura organizacional: I. Órgãos de assistência direta e imediata ao Ministro de Estado 
do qual fazem parte Gabinete; Assessoria Especial de Assuntos Internacionais; Ouvidoria; Coordenação-Geral de Atendimento ao Cidadão e Secretaria-Executiva, sendo subordinadas a esta, a Assessoria Extraordinária de Coordenação dos Grandes Eventos Esportivos; Departamento de Gestão Interna; Departamento de Planejamento e Gestão Estratégica; Departamento de Incentivo e Fomento ao Esporte; Representação Estadual no Rio de Janeiro; e Representação Estadual em São Paulo. Também fazem parte dos órgãos de assistência direta e imediata ao Ministro de Estado a Consultoria Jurídica e Autoridade Brasileira de Controle de Dopagem. II. Órgãos específicos singulares contendo a Secretaria Nacional de Esporte, Educação, Lazer e Inclusão Social, a qual pertencem: o Departamento de Gestão de Programas de Esporte, Educação, Lazer e Inclusão Social; e o Departamento de Desenvolvimento e Acompanhamento de Políticas e Programas Intersetoriais de Esporte, Educação, Lazer e Inclusão Social. Secretaria Nacional de Futebol e Defesa dos Direitos do Torcedor, que conta com os seguintes departamentos: Departamento de Futebol Profissional; e Departamento de Defesa dos Direitos do Torcedor. E a Secretaria Nacional de Esporte de Alto Rendimento da qual fazem parte o Departamento de Esporte de Base e de Alto Rendimento; e o Departamento de Excelência Esportiva e Promoção de Eventos. III. Órgão colegiado representado pelo Conselho Nacional do Esporte - CNE. (VERONEZ; GANZER; BLANK, 2013, pp. 01 e 02)

Toda esta estrutura de gestão da política de esporte está definitivamente destruída com a extinção do ME. O que foi criado no período já foi demais para os interesses lucrativos, privatistas, dos capitalistas, apesar de todos os lucros obtidos com a apropriação privada de recursos públicos, com eventos esportivos. O Estado burguês, pela sua natureza intrínseca, relacionada com a sociabilidade capitalista, com a forma política capitalista (MASCARO, 2013), entra em contradição e não suporta o acesso da classe trabalhadora ao patrimônio cultural da humanidade.

E um dos primeiros atos do governo fraudulento de Jair Bolsonaro foi a extinção Ministério do Esporte. Na sequência vamos verificar que governadores de Estados brasileiros alinhados com a política destrutivas do governo federal também extinguiram Secretarias de Esporte ${ }^{7}$. São evidencias que o Esporte perde espaço entre os governos de extrema-direita e direita. Pelos menos sete governadores, sendo quatro deles do PSL, partido de Jair Bolsonaro, eliminaram secretarias de Esporte. Paraná, Minas Gerais, Santa Catarina, Sergipe, Pernambuco, Goiás, Mato Grosso, extinguiram suas secretarias, ou esvaziaram sua estrutura administrativas e diminuíram seus recursos.

Durante os Governos de Luís Inácio Lula da Silva e Dilma Rousseff, a política de esporte foi construída a partir da escuta de vários segmentos interessados pelo esporte da sociedade brasileira e das disputas daí decorrentes. Figueiredo (2014) estudou as disputas travadas no interior das três Conferências Nacionais de Esporte $(2004,2006,2010)$ e, do conhecimento sobre política do esporte

\footnotetext{
${ }^{7}$ https://olharolimpico.blogosfera.uol.com.br/2019/01/04/fim-do-ministerio-do-esporte-gera-onda-de-extincao-desecretarias-estaduais
} 
produzido em dissertações e teses entre o período dos anos 1996 a 2011. Respondeu com sua investigação a pergunta síntese sobre as contradições na política de esporte no Brasil que se expressam a partir do governo Luís Inácio Lula da Silva, nas conferências nacionais de esporte, na produção do conhecimento (dissertações e teses) destacando que no modo de produção capitalista, em sua fase imperialista, onde as forças produtivas pararam de crescer, novos mecanismos de organização do Estado e da política são engendrados, intensificando a contradição entre capital e trabalho, verificáveis nas conferências nacionais do esporte e na produção do conhecimento. Isto ficou expresso na disputa entre o esporte para poucos, na forma de domínio/detenção dos meios de produção e reprodução e, o esporte para todos, na forma de socialização, universalização, democratização dos meios de produção e reprodução desse patrimônio cultural da humanidade e direito social, conforme consta dos documentos do governo. É no Governo de Luiz Inácio Lula da Silva que se acirram as contradições e aumentam as possibilidades para a política de esporte no Brasil, compreendidas como importantes no processo de transição para o outro modo de produção da vida e, portanto, relevante na perspectiva de inclusão, democratização e universalização nas iniciativas das ações de política de Governo e política de Estado.

A primeiro Conferência Nacional do Esporte (I CNE), foi realizada em 2004, tendo como objetivos articular e organizar as demandas dos diversos segmentos esportivos. Nesta conferencia foram propostos os fundamentos da Política Nacional do Esporte, e foi aprovada a resolução de criação do Sistema Nacional do Esporte (SNE). O conteúdo e forma do SNE deveria ser discutido na II Conferência Nacional do Esporte (II CNE), realizada em 2006. A terceira Conferência Nacional do Esporte (IIICNE) foi realizada em 2010.

Neste período, foram tecidas muitas críticas contundentes as políticas de esporte em decorrência da inversão de prioridades na pauta do governo, em decorrência da realização de grandes eventos e, não mais, a prioridade da democratização do esporte (MASCARENHAS, 2008;2015; 2012; 2008; 2011; MATIAS et al, 2015; ARAUJO, 2011; CASTELAN, 2013; MELO, 2005; VERONEZ, 2005; BUENO, 2008; MELO, 2005; TAFFAREL, 2010).

O que podemos constatar é que nos Governos de Luís Inácio Lula da Silva e Dilma Rousseff, os investimentos em Ciência e Tecnologia pelo CNPq em parcerias com o ME avançaram e, os recursos para a Coordenação de Aperfeiçoamento de Pessoal do Ensino Superior (CAPES) cresceram, com novos projetos e ampliação do financiamento. Os avanços nas agências de formação profissional foram visíveis no período de 2003 a 2016. Na formação de profissionais, ocorreu neste período a expansão do Ensino Superior. Foram mais 18 Universidades com 133 Campis Universitários. Os Institutos Federais, de 144 unidades em 2005, ampliaram para mais de 
600 em 2014. De 227,8 mil professores em 2002, o quadro docente foi ampliado para 388 mil em 2015.

A partir do Golpe de 2016, com o aprofundamento da política econômica de aplicação do ajuste fiscal, todos os investimentos regrediram. Muitos Programas e Projetos foram interrompidos e, com o anúncio da desestruturação do ME, interrompem-se políticas esportivas de grande vulto para o povo brasileiro, políticas estas reivindicadas em três Conferências Nacionais do Esporte, ocorridas em 2004, 2006 e 2010.

Reconhecemos e levamos em conta o que Mascarenhas, Matias e Athayde (2015), apresentaram no Dossiê sobre as políticas de esporte nos anos "LULA e DILMA" preocupados em utilizar as armas da crítica e a relevância social daquilo que produziram. Tratando da agenda do Esporte, do financiamento e dos programas sociais, o Dossiê apresenta dados relevantes. Destacamos que cabe, sim, a crítica aos governos do Partido dos Trabalhadores (PT), com seu arco de alianças, e esta crítica e autocrítica vem ocorrendo. Destacamos quatro pontos da autocrítica: 1) a conciliação de classe com a burguesia; 2) a adaptação ao Estado burguês; 3) a não realização de reformas estruturais de interesse da classe trabalhadora; 4) o pacto de governabilidade com as elites, e não assentado em acordos com a classe trabalhadora para atender suas reivindicações. Mas, esta crítica somente procede se inserida na análise rigorosa da correlação de forças presentes neste período de 2003-2016; se inserida na análise histórica do Brasil desde os 1500 e a estrutura escravocrata de poder construída e alicerçada pelas oligarquias, pelos empresários, pelos detentores do poder econômico, ideológico e político; se inserida na explicação sobre os avanços da direita e da extrema-direita no mundo e, em especial, no Brasil; inserida na honestidade de admitir o contraditório, os acertos, as realizações, as consequências positivas para a classe trabalhadora.

Mas, qual foi afinal a política de esporte no período de 2003-2016 e que agora está completamente desmantelada e, quais as perspectivas para o próximo período?

\section{POLITICA NACIONAL DO ESPORTE. A caracterização pelos programas e ações realizadas}

O que se segue pode ser localizado em documentos, relatórios e nas páginas ainda no ar do Ministério do Esporte, que demonstram a forma como se estruturou o Ministério do Esporte, suas finalidades e suas realizações. Estas informações foram obtidas e sistematizadas, também, a partir de um levantamento do material disponível no LEPEL/FACED/UFBA. Contamos também, com a disponibilidade da professora Cassia Damiani, que dedicou sua vida profissional, no período de 2003 a 2016, para atuar junto ao Ministério do Esporte e compartilha conosco seu conhecimento. 
Com certeza sua tese de doutorado, em elaboração, junto a UFRGS, sob orientação do professor Dr. Alberto Reppold Filho, trará à ciência a Política Nacional do Esporte, em seu movimento histórico, demonstrando o que não somos capazes de compreender de imediato. Trará o ineditismo de um Sistema Nacional do Esporte e seu desenvolvimento no período de governo democrático e popular, a saber, de 2003 a 2016.

Temos, portanto, documentos referentes: a) as políticas de esporte, educação, lazer e inclusão social e b) as políticas de esporte de alto rendimento com programas transversais sobre a políticas de infraestrutura e, c) as políticas de ciência e tecnologia e; d) ações estratégicas temporárias relacionadas a grandes eventos esportivos.

Foram Ministro do Esporte durante os mandatos presidenciais de Luís Inácio Lula da Silva e Dilma Rousseff, o deputado Federal Agnelo Queiroz (PCdoB), que assumiu o então recém-criado Ministério do Esporte em janeiro de 2003. Em 31 de março de 2006, o cargo foi assumido interinamente por Orlando Silva Júnior (PCdoB), o mais jovem ministro do Brasil, com 34 anos, sendo confirmado no cargo em 2007 e ocupando o cargo até 2011. No dia 31 de outubro de 2011 tomou posse o Ministro Aldo Rebelo (PCdoB) até 2014. No dia 2 de janeiro de 2015, o deputado federal George Hilton (PRB) assumiu a pasta. No dia 30 março de 2016 assume o Ministério do Esporte Ricardo Leyser Gonçalves (PCdoB). Em 12 de maio de 2016 tomou posse como Ministro do Esporte o deputado federal Leonardo Picciani (MDB). Em 01 de janeiro de 2019, no governo de Jair Bolsonaro, a pasta do esporte foi incorporada ao Ministério da Cidadania, juntamente com o Ministério da Cultura e Ministério de Desenvolvimento Social. O atual Ministro é Osmar Terra (MDB).

Esta junção recebeu severas críticas da professora Cassia Damiani (2018) pelo fato de que, nesta estrutura não existirá possibilidade de continuar o trabalho que vinha sendo desenvolvido no Ministério do Esporte. Ocorrerá, sim, um grande retrocesso.

Quanto as Políticas de Esporte, Educação, Lazer e Inclusão Social, localizamos nos documentos do LEPEL/FACED/UFBA, nos sítios na internet, bem como, na produção teórica sistematizada pela professora Cassia Damiani o seguinte:

(1) Programa Segundo Tempo - PST que busca promover a inclusão social da população que historicamente esteve à margem de seus direitos de cidadania. Destinouse a oferecer o acesso à prática e à cultura do esporte educacional e do esporte escolar com múltiplas modalidades esportivas, da vivência ao aprendizado. Seus núcleos funcionam em turnos opostos aos das aulas nas escolas. Existiu também Ação Inter setorial Esporte da Escola, em parceria com os Ministérios do Esporte e o da 
Educação, envolvendo duas ações: Programa Segundo Tempo do ME com o Programa Mais Educação do MEC integrados com a finalidade de ampliar a abrangência e dar capilaridade e escala ao programa esportivo nas escolas públicas de Educação Básica com menor IDEB (Indice de desenvolvimento da Educação Básica), o que possibilitaria universalizar o acesso de crianças e jovens escolares ao esporte, transformando a perspectiva focal e assistencialista do programa.

(2) Programa Atleta da Escola, em parceria com o Ministério da Defesa, voltado para escolares de 12 a 17 anos, matriculados na Educação Básica, cujos eixos orientadores visam o incentivo e à democratização das práticas esportivas nas escolas; ao desenvolvimento e à difusão de valores olímpicos e paralímpicos entre estudantes do Ensino Fundamental e Médio; ao estímulo à formação do atleta escolar; bem como, à identificação e orientação de jovens talentos.

(3) Esporte e Lazer da Cidade - PELC e o Programa Vida Saudável. Desenvolvidos com a intenção de promover o acesso às práticas corporais diversas, como o esporte recreativo e de lazer, para crianças, jovens e adultos, contemplando idosos e pessoas com deficiência. Desenvolvidos em todos os estados brasileiros. Os núcleos implantados em cidades e comunidades oferecem atividades esportivas lúdicas que, de forma autônoma, resgatam as práticas com identidades próprias de cada local e formam gestores públicos de esporte e lazer. Valorizava as atividades próprias de populações com tradições culturais particulares, como quilombolas, indígenas e comunidades rurais.

(4) Plano Nacional do Esporte de Alto Rendimento, contou com programas, projetos e ações voltadas para o alto rendimento e ações relativas ao Futebol e ao Controle à Dopagem. Os eixos do Plano Nacional do Esporte de Alto Rendimento eram: Estruturação das modalidades olímpicas e paraolímpicas, com o Programa Bolsa Atleta e o Programa Bolsa Pódio, e Ação de apoio às modalidades esportivas, o Projeto Brasil Medalhas 2016; Formação da Rede Nacional de Treinamento, envolvendo os Centros de Iniciação ao Esporte, os Centros Regionais de Treinamento, os Centros de Treinamento por Modalidades e os Centros Nacionais de Treinamento; Ampliação da prática de esporte no país, fazendo interface com o Programa Atleta da Escola, Programa Segundo Tempo, Programa Segundo Tempo/Mais Educação, PELC e, com a construção de quadras nas escolas de Ensino Fundamental e implantação dos Centros de Iniciação ao Esporte. Outro aspecto das políticas do esporte de alto rendimento são as relacionadas às Ações para o Futebol, como: Programa de Modernização da 
Gestão e de Responsabilidade Fiscal do Futebol Brasileiro - PROFUT, que trata dos princípios de práticas de responsabilidade fiscal e financeira e de gestão transparente e democrática para entidades esportivas profissionais de futebol, das ações para garantir a recuperação de dívidas pela União, e da Autoridade Pública de Governança de Futebol - APFUT que se ocupa de enfrentar a questão da gestão temerária no âmbito das entidades esportivas profissionais de futebol. Comissão Nacional de Prevenção e Segurança nos Espetáculos Esportivos (Consegue), responsável em promover encontros específicos para a prevenção da violência entre as torcidas organizadas. Implantação do Canal do Torcedor, com o objetivo de acompanhar a vigência e acesso dos laudos de cada estádio, e a validade do Sistema Brasileiro de Classificação de Estádios de Futebol (SBCE). Ações respaldadas no Estatuto do Torcedor, Lei $\mathrm{n}^{\mathrm{o}}$ 10.671, de 15 de maio de 2003, pacto entre os Ministérios do Esporte e da Justiça, a Confederação Brasileira de Futebol, o Conselho Nacional de Justiça e o Conselho Nacional dos Procuradores Gerais do Ministério Público dos Estados e da União. Outro destaque da política para o Alto rendimento foi o Estímulo ao futebol feminino. Quanto a infraestrutura, a construção do Centro de Referência para o Futebol Feminino no país, o Parque Tecnológico Itaipu Brasil, em Foz do Iguaçu, por meio de projeto aprovado pela Lei de Incentivo ao Esporte. Foram incentivadas iniciativas para a organização das atletas de futebol feminino junto aos clubes e federações, fornecidos apoios à realização de competições nacionais e internacionais, como o III Campeonato Brasileiro de Futebol Feminino - Brasileirão, que contou com o patrocínio da Caixa Econômica Federal e da Confederação Brasileira de Futebol, à II Copa Brasil Universitária de Futebol Feminino, em parceria com a Confederação Brasileira de Desporto Universitário (CBDU), envolvendo todas as unidades da Federação, além da II Copa Brasil Escolar de Futebol Feminino, com a participação de equipes de todos os estados brasileiros e do Distrito Federal. Ações de Controle à Dopagem estão incluídas na política de esporte de alto rendimento. Foi criada a Autoridade Brasileira de Controle de Dopagem (ABCD), para combater a Dopagem no Esporte e a proteção dos atletas limpos, além de atuar na informação, educação, prevenção, inteligência e ação antidopagem, bem como para disponibilizar os mais avançados recursos para o Plano de Testes e para a definição conjunto de análises a serem feitas e na educação de atletas.

(5) Políticas Ciência e Tecnologia focou na produção do conhecimento cientifico para o desenvolvimento da Politica Publica de Esporte. Estudos apoiados e demandados pelo ME, e trazem avanços conceituais para o desenvolvimento teórico do 
campo das políticas públicas, contribuindo para o processo de decisão sobre os rumos da política esportiva.

(6) Projeto Referências do Esporte de Alto Rendimento, foi demanda do Ministério do Esporte, por meio da Secretaria Nacional de Esporte de Alto Rendimento SNEAR, em parceira com o Centro de Estudos Olímpicos da Escola de Educação Física da Universidade Federal do Rio Grande do Sul, que desenvolveu, desde o ano de 2013, o mapeamento situacional das modalidades olímpicas e paraolímpicas no país. O Projeto Referências tinha o propósito de subsidiar a elaboração do Plano Nacional do Esporte de Alto Rendimento. (REPPOLD FILHO, 2013; 2016; 2009; 2017)

(7) Projeto Inteligência Esportiva, também encomendado pelo Ministério do Esporte, em parceria com Centro de Pesquisa em Esporte, Lazer e Sociedade (CEPELS) da Universidade Federal do Paraná. O objetivo do projeto foi produzir, sistematizar, analisar e difundir informações sobre as políticas para o esporte de alto rendimento no Brasil. Existe hoje uma base de dados científicas integrados nacional e internacionalmente (LILACS, MEDLINE, SCIELO e Portal de Periódicos Capes), como fruto deste trabalho. Sob a Coordenação do Professor Mezzardi (2014; 2016) existem dados em publicação sobre os programas Bolsa-Atleta e Bolsa Atleta Pódio, a Rede Nacional de Treinamento, os Jogos Escolares da Juventude, além da produção científica e dos grupos de pesquisa brasileiros na área do esporte, com destaque para os esportes olímpicos e paraolímpicos.

\section{(8) Rede CEDES- Centro de Desenvolvimento de Esporte Recreativo e de} Lazer, estimulou com apoio orçamentário e incentivou com problemáticas desafiadoras e inovadoras grupos de pesquisa a produzir e difundir conhecimentos voltados para o aperfeiçoamento e a qualificação de projetos, programas e políticas públicas de esporte recreativo e de lazer, por meio da produção e difusão de conhecimentos em diferentes instâncias. As publicações que tratam do balanço da Rede CEDES demonstram que houve várias fases, desde a sua criação em 2004, quando foi se aperfeiçoando e buscando mecanismos mais seguros para a sua estruturação. A Rede CEDES poiou nesse período, 149 pesquisas de 90 grupos com 59 pesquisadores envolvidos. Buscou mecanismos para incentivar e reconhecer iniciativas científicas, tecnológicas e pedagógicas, voltadas à qualificação de políticas públicas, criando o Prêmio Brasil de Esporte e Lazer de Inclusão Social, que nas edições de 2008 e 2010, em diversas categorias, premiou 209 pesquisadores (SCHWARTZ, 2010). Em 2015, houve a implantação, em todas as unidades federativas, de 27 Centros de Desenvolvimento de 
Pesquisas da Rede CEDES, como polos aglutinadores de grupos de pesquisas e instituições de ensino superior. Isso foi considerado, pelos pesquisadores da área, um marco para consolidação e estruturação da Rede, tanto na organização, quanto no financiamento que passou a ser estipulado pelos editais. A Rede também visava à viabilização de eventos científicos nacionais e internacionais, o que também foi ampliado com estímulos dados pela realização dos grandes eventos esportivos.

(9) DIAGNOSTICO NACIONAL DO ESPORTE - DIESPORTE. O Projeto foi executado pela UFBA, articulada com as Universidades UFRGS, UFRJ, UFG, UFAM, UFS, por encomenda do ME, com financiamento do Conselho Nacional de Desenvolvimento Cientifico e Tecnológico (CNPq) e Financiadora de Estudos e Projetos (FINEP). O Projeto foi coordenado pelos professores Cassia Damiani (ME), Ailton Santana (UFS) e Celi Taffarel (UFBA). O intuito era a tomada de decisão estratégica para o desenvolvimento do Esporte no Brasil, a partir de Políticas de Estado e de Governo democrático e popular, assentadas em um rigoroso e extensivo, sistemático e permanente Diagnóstico Nacional do Esporte. As variáveis estudadas, o praticante ou não do esporte, legislação esportiva, infraestrutura, gestão e administração do esporte e financiamento esportivo, nos permitiram concluir que: a maioria da população não pratica esporte, que a juventude deixa de praticá-lo porque precisa trabalhar, que a infraestrutura esportiva é na maior parte privatizada, que a legislação esportiva carece de avanços para além do esporte de alto rendimento e dentro dele do futebol, e que o financiamento do esporte, é na sua maioria, de ordem privada e, quando o financiamento advém do Estado, a prioridade tem sido o alto rendimento. O DIESPORTE demonstrou que cabem, sim, iniciativas estatais de vulto para criar um Sistema Nacional do Esporte, para fomentar, incentivar, propiciar práticas corporais, considerando principalmente o sistema educacional, o sistema de saúde, o sistema de cultura, o sistema comunitário, popular e, o sistema de alto rendimento. Paralelo ao DIESPORTE, o ME, nas gestões dos presidentes Luís Inácio Lula da Silva e Dilma Rousseff, veio incentivando a pesquisa e a criação de um Sistema Nacional do Esporte, construção interrompida com o Golpe de 2016, mas retomada na tese de doutorado da professora Cassia Damiani (2019). A partir da metodologia do Diesporte (2013), foram realizadas outras duas pesquisas em parceria com o IBGE que contribuíram para a atualização do diagnóstico do esporte nacional. São elas: Pesquisa Nacional por Amostra de Domicílios (PNAD), que tem por objetivo a produção de informações básicas para o estudo do desenvolvimento social e econômico do País. Em 2015, foi acordada a inclusão de um 
suplemento de esporte junto à PNAD, que trata do perfil do praticante em grande escala nacional, que agregaria insumos para o acompanhamento e avaliação da efetividade das políticas do Ministério do Esporte, inclusive em nível municipal. Outra iniciativa foi a Pesquisa de Informações Básicas Estaduais (ESTADIC) e Pesquisa de Informações Básicas Municipais (MUNIC) que são pesquisas realizadas pelo IBGE em todos os estados e municípios brasileiros e levantam informações relacionadas à gestão dos governos estaduais e administrações municipais. Com o acordo com o IBGE, realizado em 2015 essas pesquisas também contemplariam suplementos visando o levantamento de informações sobre o esporte no âmbito das esferas municipais e estaduais sobre a identificação, localização e tipo da infraestrutura esportiva pública, bem como, dados sobre a gestão esportiva nessas esferas governamentais.

Até o Golpe de 2016, os Ministros ligados ao PCdoB, com suas equipes, tomaram iniciativas que envolveram a integração programática de diversos setores de políticas sociais, relacionadas com o esporte, bem como, ações de monitoramento e avaliação, para acompanhar e controlar as ações que envolveram pactos federativos - municípios, estados e governo federal. Os Programas Transversais, por sua vez, perpassavam todos os âmbitos da Política Nacional do Esporte e contribuíam com os objetivos e estratégias definidas na política. Duas se destacam: (a) políticas de infraestrutura; b) políticas de ciência e tecnologia contidas na Política Nacional do Esporte. A infraestrutura visava modernizar, democratizar, ampliar. O que foi realizado consta do Balanço da Presidência da República 2003 - 2010 (BRASIL, 2010). Constam aí as obras que foram assumidas como compromissos governamentais e ficaram como legados dos Jogos Olímpicos e Paraolímpicos Rio 2016.

Quanto a iniciativas temporais temos os grandes eventos assumidos pelos governos de Luís Inácio Lula da Silva e Dilma Rousseff. A Copa Mundial de Futebol FIFA, 2014, os Jogos Olímpicos e Paralímpicos Rio, 2016. Foram realizados ainda outros eventos como os Jogos Mundiais Militares 2011, Copa das Confederações FIFA, 2013, tudo isto inaugurado com a realização dos Jogos Pan-americanos e Jogos Parapan-americanos Rio 2007.

Ficou pendente, com o Golpe de 2016, uma tradução que estava em vias de ser concretizada, do livro de autoria do Professor Dr. Mario Alighiero Manacorda, em quatro volumes, sobre a História do Esporte intitulado "DIANE E LE MUSI: Tremila anni di sport nella literatura”. Ou seja, Três mil anos de esporte na literatura. Esta demanda foi localizada pela equipe do DIESPORTE na Itália, onde iniciaram-se as tratativas, não concluídas, em decorrência do Golpe de 2016. 
Mas, tudo está interrompido. A burguesia, a elite, a classe alta, sustentada ideologicamente pela classe média (SOUZA; 2015; 2017), não suporta repartir, democratizar, universalizar com a classe trabalhadora o patrimônio cultural. É da natureza do capitalismo a forma política do Estado burguês (MASCARO, 2013). A burguesia disputa e, se necessário for destrói, desmonta, como está desmontando as frágeis estruturas de instituições democráticas construídas no último período, em especial durante os governos de Luís Inácio Lula da Silva e Dilma Rousseff. Estas formas minimamente democráticas, são insuportáveis à lógica mercantil, exploradora, do capital. Os impactos desta interrupção e desta devastadora destruição serão sentidos, principalmente pelos jovens, estudantes, povos tradicionais, do campo, dos rios e das florestas, os indígenas, quilombolas, campesinos, as populações constituídas da classe trabalhadora que vivem com menos de dois salários mínimos por mês, que é a grande maioria que foi beneficiada. Teremos impactos nos Grupos de Pesquisa sobre o Esporte que eram financiados pela Rede CEDES, nos projetos de extensão das universidades financiados com recursos públicos e desenvolvidos em parceria com governos Estaduais e Municipais, nas políticas do esporte participação, esporte comunitário, bem como, no esporte de alto rendimento. Basta conferir no próprio portal do $\mathrm{ME}$ e vamos verificar que no Esporte de Alto Rendimento são mais de 6 Programas e Projetos e, no Esporte - Educação, Lazer e Inclusão Social, mais de 12 Programas e Projetos que estão ameaçados com a extinção do ME. Por exemplo projetos e ações fadados a interrupção: Plano Brasil Medalhas; Rede Nacional de Treinamento; Centro de Iniciação ao Esporte; Centros Olímpicos de Treinamento; Bolsa Atleta; Segundo Tempo; Atleta na Escola; Brincando com Esporte; PELC; Vida Saudável; Futebol Feminino; Seleções do Futuro; Sistema Nacional do Esporte; Lei de Incentivo ao Esporte; DIESPORTE; Estádio Mais; Legado Esportivo. Ficam comprometidas as ações da Secretaria de Esporte, Educação, Lazer e Inclusão Social. Segundo dados do portal do ME, o PELC completou 14 anos tendo realizado um trabalho de relevância social. A Rede CEDES implantada como ação programática do ME em 2003. Essa iniciativa estava voltada, para o fomento da pesquisa integrada ao Programa Brasil Potência Esportiva - "Estudos e pesquisas científicas e tecnológicas para o desenvolvimento do esporte" - , gerenciada pelo Departamento de Ciência e Tecnologia do Esporte. Em 2004, a ação "Estudos e pesquisas", transformou-se na Rede CEDES, integrando o conjunto de atividades do PELC direcionado para o Desenvolvimento Científico e Tecnológico do Esporte e do Lazer. O último edital que compreendeu essa integração com o PELC foi publicado em 2011. Do histórico da Rede CEDES conclui-se que esta viveu seis momentos importantes: 1) quando foram estabelecidas parcerias com grupos de pesquisas de Cursos de EF das Universidades públicas brasileiras para apoio a pesquisas voltadas ao esporte recreativo e lazer; 2) ampliação de apoio ao aprofundamento e à consolidação de pesquisas que qualifiquem a política de esporte e lazer do País; 
3) criação, em 2007, de Edital Público anual para seleção de projetos para apoio a pesquisas de esporte e lazer, que, em 2011, realizou sua quarta edição; 4) ampliação do fomento à pesquisa social sobre Políticas Públicas de Esporte e Lazer e o investimento na gestão do conhecimento produzido pela Rede CEDES, sua ampla sistematização e socialização, busca contribuir com a qualificação das demais ações do PELC e a capacitação de gestores, agentes e estudiosos de esporte e lazer brasileiros e de outros países; 5) identificado pela colaboração do ME e CNPq na chamada ME/CNPq n.091/2013, na qual três linhas de pesquisa foram apoiadas pela Rede CEDES; 6) Chamada Convite de novos projetos no ano de 2014, além da participação no Edital do Programa de Extensão Universitária (ProEXT) 2015. Destacamos estes programas porque tivemos a oportunidade de participar efetivamente destas importantes iniciativas que, neste momento estão interrompidas.

\section{CONCLUSÃO PROVISÓRIA}

Decorrente de todas os programas, projetos, ações desenvolvidas no período entre 20032016, dos governos de Luís Inácio Lula da Silva e Dilma Rousseff, temos um vastíssimo acervo bibliográfico, de material didáticos de alta qualidade, que ainda está por ser levantado, catalogado, analisado, disponibilizado. Mas, temos, principalmente, os dados empíricos que nos permitem afirmar que a Política Nacional do Esporte, durante os Governos de Luís Inácio Lula da Silva e Dilma Rousseff respondeu a grades desafios, em meio a grandes contradições e disputas, e deixou um legado importante, que precisa ser recuperado, resgatado, para instituirmos, em um governo democrático e popular, o Sistema Nacional do Esporte, integrado ao Sistema Único de Saúde, ao Sistema Educacional, ao Sistema de Seguridade Social, ao Sistema de Segurança Pública, ao Sistema de Transporte Urbano, ao Sistema de Direito a Cidade, entre outros, na perspectiva da emancipação humana e da superação do modo de vida capitalista. Para tanto será necessária uma forte resistência ativa da classe trabalhadora, para enfrentar a avalanche destrutiva que está se abatendo sob as políticas sociais no Brasil (SAVIANI e DUARTE, 2012; FRIGOTTO, 2018; FREITAS; 2019)

Mas, as análises críticas sobre as lutas populares na América Latina e os governos Progressistas (ARKONADA, KLACHCO; 2017) demonstram a geopolítica da intervenção de países imperialistas, em especial os Estados Unidos, para infringir Golpes, em especial em governos e governantes que avançam nas frágeis conquistas democráticas na América Latina. Estes ataques vão desde orientações do Banco Mundial (2017), com seus “Ajustes Justos” para que se privatizem as universidades, até a perseguição política usando o aparato jurídico (LAWFARE) para prender 
opositores, como é o caso da prisão do ex-presidente Luís Inácio Lula da Silva. Segundo Benigno Nunes Novo (2018) “Trata-se do uso da lei (law) como instrumento de guerra e destruição do outro (warfare), onde não se respeita os procedimentos legais e os direitos do indivíduo que se pretende eliminar. Tal prática é planejada de forma a ter toda uma aparência de legalidade, com a ajuda da mídia, além dos agentes perpetradores". (NOVO, 2018).

O Golpe de 2016 no Brasil contra a presidenta legitimamente eleita com 54 milhões de votos é uma demonstração disto (JINKINGS, Ivana; DORIA, Kim; CLETO, Murilo (Org.) 2016; e SOUZA; 2015; 2016; 2017; 2019). A Cronologia do Golpe conforme demonstram com dados empíricos o Comitê dos Servidores Federais, (2018), a partir da descoberta do pre-sal, deixa evidente que a ambição desenfreada do imperialismo e seus vassalos entreguistas, entre os quais contam-se setores militares, empresariais, do judiciário, do legislativo e executivo brasileiro, somados aos pentecostais e demais crentes de direita, a grande mídia privada, aliados ao imperialismo norte-americano, é apoderar-se dos bens públicos, das fontes energéticas e da biodiversidade e transformar o que deveria ser direito e serviços públicos em mercadorias comercializadas por setores privados da economia capitalista.

As revelações sobre a operação Lava Jato e a denúncia do The Intercep, que já vinham sendo apontadas anteriormente, conforme descrito por Giovanaz (2018), bem como, o Dossiê sobre Governo Bolsonaro (Margem Esquerda, N. 32, 2019) trazem evidencias que a barbárie está em curso acelerado no Brasil. Trata-se no plano nacional da expressão das contradições do capital e sua forma política incompatível com a democracia, com a repartição de riquezas, com patrimônio público, com direitos e conquistas.

As evidencias desta avassaladora destruição podem se identificadas nas evidencias da destruição de políticas públicas inclusivas, democráticas, universalistas. Mas, a Resistência ao Golpe (PRONER; CITTADINO; TENENBAUM; RAMOS FILHO; 2016) está sendo evidenciada nos atos públicos, por exemplo, dos dias 15 de maio, 30 de maio, 15 de junho de 2019 e 12 de julho de 2019. A classe trabalhadora reage ao que lhes é sensível de imediato como são os cortes na educação, a aprovação de reformas como a trabalhista já concretizada e, a perversa contrarreforma da previdência que está em curso e penaliza os mais pobres. A classe trabalhadora e suas organizações reagem também ao que não é visível de imediato, como o crescimento de formas escravocratas de relações de trabalho (GORENDER; S/D; 2004; 2016); a quebra do sistema de proteção do trabalho e do trabalhador (CASTIONE; 2008); o pacto dos donos do poder para perpetuar uma sociedade cruel forjada na escravidão (SOUZA; 2017); o crescimento do genocídios dos negros e negras (SOUZA (org.), 2019; FERNANDES, 2005; 2017; 2019; 2019a e NASCIMENTO, 1978); o crescimento do ódio como política (GALLEGO, 2018); o crescimento 
do feminicidio (BOITO, 2016; DAVIS, 2016; SINASEFE-IFBA, S/D; ANDES-SN, 2016); SAFFIOTI, 2013; MIGUEL, 2018; MIGUEL E BIROLI, 2014); a instalação paulatina do Estado autoritário e suas formas de dominação no Brasil contemporâneo (MATTOS (org.), 2017); LENIN; 2007); BOGO; 2018); e, o aprofundamento do Estado de Exceção (VALIM, 2017).

A forma política do Estado enquanto uma forma social capitalista, permeada de conflitos e contradições (MASCARO, 2013), a caracterização da perversa burguesia brasileira (GORENDER, S/D; 2016; 2004; SOUZA, 2015) e o crescimento de tendências fascistas (TROTSKY, 2018; ZETKIN, 2019), ou no mínimo o crescimento da Nova Direito (CASIMIRO, 2018), não nos deixa margem de segurança e tranquilidade.

A luta de resistência nunca foi, não está e, não será nada fácil. A ditadura do grande capital (IANNI; 2019) está nos levando a Guerra Hibrida (KORYBKO, 2018). O crescimento de um regime autoritário (FERNANDES; 2019) é evidente na forma de governar por portarias, decretos, leis que inclusive são inconstitucionais. As forças destrutivas ligadas aos setores rentistas e fundomonetarista, com seus ajustes estruturais, estão destruindo as forças produtivas. (MONTORO, 2014; 2018). Não temos tempo a perder. É necessária a resistência ativa imediata, para defender direitos e conquistas. O que precisa ficar evidente, porque os dados empíricos não o negam, é que a política econômica do ultraliberalismo, aplicada no Brasil, trouxe consigo as maiores mazelas da humanidade e podem culminar na forma atual de regimes nazifascistas. Isto significa que a política é rebaixada e subserviente à lógica do capital e não à racionalidade humana civilizatória. Consequentemente, o Estado, forma política do capitalismo, passa a servir exclusivamente ao capital, e sua sociabilidade exploradora, em detrimento dos interesses da Classe Trabalhadora (MASCARO, 2013). É disto que se trata: estamos avançando na tendência da destruição das forças produtivas. Harvey $(2016 ; 2018)$ designa este período como o de aprofundamento das contradições do capitalismo que sinalizam para seu final. Período de acentuada loucura da razão econômica.

Mas, a resistência dos que defendem as políticas sociais públicas de Governo e de Estado, democráticas e populares, voltadas para as reivindicações dos trabalhadores, contra a Barbárie (CASSIO, 2019), políticas públicas democráticas, inclusivas, participativas, universais, nas áreas de educação, cultura, saúde, esporte, segurança pública, habitação, meio ambiente, comunicação, tributarias, reforma agraria, entre outras, apresentam o horizonte teleológico de superação do Capitalismo e sua forma política, o Estado burguês (MARX, ENGELS, LENIN, TROTSKY, 2018); (MASCARO, 2018); (FREITAS, 1987). E esta não é uma tarefa só dos profissionais do esporte e dos esportistas. É de toda a classe trabalhadora. A classe trabalhadora deve chamar para si tais tarefas, em suas dimensões de tarefas imediata, mediata e histórica (FREITAS, 2018; PRASHAD, S/D; MARX; ENGELS; LENIN; TROTSKI, 2018). Isto implica na construção, reconstrução, na 
defesa dos instrumentos de luta social dentro do que consta a defesa do Partido Político (FERNANDES, 2019; A VERDADE, 2019), em especial, os Partidos de Esquerda (PT, PCdoB entre outros), considerando o que foram capazes de realizarem em termos de politica do esporte, apesar de todas as contradições, reconhecidas e dos erros cometidos, em 13 anos de mandato no governo federal e o que serão capazes de realizar, daqui em diante, tirando as lições da história. Cabe, sim, compreendermos as lições derivadas da prática, para que na próxima oportunidade, os avanços para a classe trabalhadora sejam bem maiores do que os retrocessos e atinjam o ponto de irreversibilidade necessária. E isto passa, sim, na compreensão da forma política do Estado, seus limites, suas contradições e suas possibilidades, frente as necessidades vitais dos seres humanos. E isto passa por um profundo ajuste nas forças de esquerda, na perspectiva da construção da frente única anticapitalista, anti-imperialista rumo a construção da sociabilidade socialista.

O desafios e o fardo do tempo histórico (MÉSZÁROS, 2002; 2003; 2007) que pode ser caracterizado por suas contradições "fundamentais, mutáveis e perigosos" (HARVEY, 2016; 2018), tempo que indica as tarefas, tempo de destruição de forças produtivas (MONTORO, 2014; 2018) é que o tempo é tempo de "cambiar el mundo". Segundo Hobsbawm (2011, p. 424), “Há que se cambiar el mundo... Ha llegado la hora de tomarse en serio a Marx".

Destacamos, ainda, que esta luta não se dará fora: 1) da ação de governos democráticos e populares e por isto, a liberdade imediata do ex-presidente Luís Inácio Lula de Silva, é imprescindível; 2) da união de trabalhadores da cidade e do campo; 3) de lutas econômicas, ideológicas e políticas articuladas, pela insatisfação das massas que erguerão suas reivindicações concretas; 4) pelos organismos de luta da classe trabalhadora (A VERDADE, 2019) que mobilizarão, organizarão e atuarão nos enfrentamentos e, 5) a materialidade mínima suficiente para que se trave a luta pelo socialismo (MASCARO, 2018, p. 190).

\section{REFERÊNCIAS}

A VERDADE. As tarefas de construção da 4 Internacional. Revista Teórica da 4. Internacional. N. 99-100, fevereiro de 2019.

ARKONADA, Katu; KLACHKO, Paula. As lutas populares na América Latina e os governos progressistas. Crises e desafios na atualidade. São Paulo: Expressão Popular, 2017.

ADUSP - Associação dos Docentes da USP. O controle ideológico na USP: 1964-1978. São Paulo: ADUSP, 2004.

ANTUNES, Ricardo. O privilégio da servidão: o novo proletariado de serviços na era digital. São Paulo: Boitempo, 2018. 
ARAUJO, S. M. Conselhos estaduais de esporte e lazer no nordeste brasileiro: participação popular e controle social em questão. São Luis: EDUFMA, 2011.

ARNS, D. Paulo Evaristo. Brasil: Nunca mais - Um relato para a história. Ditadura militar no Brasil de 1964-1985. Rio de Janeiro: Vozes, 1985.

ANDES-SN. Projeto do capital para a educação: análise e ações para a luta. Brasília: ANDESSN. mar. 2016a.

ANDES-SN. Contra todas as formas de assédio, em defesa de direitos das mulheres, das/os indígenas, das/os negros, e das/os LGBT. Brasília: ANDES-SN. jul. $2016 \mathrm{~b}$.

BANCO MUNDIAL. Um ajuste justo - Análise da eficiência e equidade dos gastos públicos no Brasil. Banco Mundial. 21/11/2017. In:

https://www.worldbank.org/pt/country/brazil/publication/brazil-expenditure-review-report Acesso dia 20/06/19 às 20:35h.

BANDEIRA, Luís Alberto Moniz. Relações Brasil-EUA no contexto da globalização. São Paulo: SENAC São Paulo, 1998.

BANDEIRA, Luís Alberto Moniz. As relações perigosas: Brasil-Estados Unidos (De Collor a Lula, 1990-2004). Rio de Janeiro: Civilização Brasileira, 2004.

BELTRÃO, José Arlen; TAFFAREL, Celi N. Zulke. A ofensiva dos reformadores empresariais E a resistência de quem defende a educação pública. Retratos da escola, Brasília, v.11, n.21, p.587601, jul./dez. 2017.

BOITO; Misa (Org.) A luta contra a opressão da mulher: recuperando uma abordagem de classe. São Paulo: Nova Palavra, 2016.

BOGO; Ademar. Marx e a superação do estado. São Paulo; Expressão Popular, 2018.

BRASIL. Ministério do Esporte. Balanço de gestão 2003/2010. Brasília: Ministério do Esporte, 2011.

BRASIL. Ministério do Esporte. Política nacional do esporte, 2005

BUENO, Luciano. Políticas públicas do esporte no Brasil: razões para o predomínio do alto rendimento. Tese (Doutorado em Administração Pública e Governo). Fundação São Paulo: Getúlio Vargas, 2008.

CARNEIRO, Henrique. As raízes do neofascismo no século XXI. In: TROTSKY, Leon. Como esmagar o fascismo. São Paulo: Autonomia Literária, 2018.

CASIMIRO; Flavio. A Nova Direita: aparelhos de ação política e ideológica no Brasil contemporâneo. São Paulo. Expressão Popular, 2018.

CASSIO; Fernando. Educação contra a barbárie. Por escolas democráticas e pela liberdade de ensinar. São Paulo: Boitempo, 2019. 
CASTELAN, Lia Polegato. As conferências nacionais do esporte na configuração da política esportiva e de lazer no governo Lula (2003-2010). Dissertação (Mestrado em Educação Física) Campinas: UNICAMP, 2011.

CASTELlANi FILHO, Lino. Educação Física no Brasil. A história que não se conta. Campinas/SP: Papirus, 1988

CASTIONE; Remi. O sistema de proteção ao trabalho no Brasil. Campinas/SP: Autores Associados, 2008.

COMITÊ DOS SERVIDORES PÚBLICOS FEDERAIS. Cartilha: a cronologia do golpe, 2018.

DAMIANI, Cassia. Ministério da Cidadania: O esporte submetido a assistência social? Disponível em: http://www.vermelho.org.br/noticia/317246-1. Acesso em: 27 jan.2019.

DAVIS; Ângela. Mulheres, raça e classe. São Paulo: Boitempo, 2016.

DIAS JÚNIOR, Elson Moura e LIMA; Thiago Firmino. MNCR: 10 anos na luta pela regulamentação do trabalho. Feira de Santana/BA: Editora da UEFS, 2012.

DOURADO, Luís Fernandes. Plano nacional de Educação: o epicentro das políticas de estado para a educação brasileira. Goiânia: Editora da Imprensa e Universitária, 2017.

ENGELS, Friedrich. A origem da família, da propriedade privada e do Estado. 3.ed. São Paulo: Expressão Popular, 2012.

ENGELS, Friedrich. Do socialismo utópico ao socialismo científico. São Paulo: Moraes, s.d.

FERNANDES; Florestan. A revolução burguesa no Brasil. São Paulo: Globo, 2005.

FERNANDES; Florestan. Significado do protesto negro. São Paulo: Expressão Popular: 2017.

FERNANDES; Florestan. Apontamentos sobre "teoria do autoritarismo". São Paulo: Expressão Popular, 2019.

FERNANDES; Florestan. Reflexões sobre a construção e um instrumento político. São Paulo. Expressão Popular, 2019.

FREITAS, Luiz Carlos de. Projeto histórico, ciência pedagógica e "didática”. Educação \& Sociedade, São Paulo, Ano IX, n. 27, p. 122-140, 1987.

FREITAS, Luiz Carlos de. A reforma empresarial da educação - nova direita, velhas ideias. São Paulo; Expressão Popular, 2018.

FRIGOTTO, Gaudêncio (Org.). Escola "sem" partido: esfinge que ameaça a educação e a sociedade brasileira. Rio de Janeiro: UERJ; LPP, 2017.

FRIGOTTO, Gaudencio; QUEIROZ, Felipe; PENNA, Fernando. Educação democrática: antidoto ao escola sem partido. Rio de Janeiro: LPP/UERJ, 2018. 
GALLEGO; Esther Solano. O ódio como política: a reinvenção das direitas no Brasil. São Paulo: Boitempo, 2018.

GEOVANAZ; Daniel. Dossiê Lava Jato: um ano de cobertura critica. São Paulo/SP: Outras expressões, 2018.

GORENDER; Jacob. A burguesia brasileira. São Paulo: Brasiliense, 2004.

GORENDER; Jacob. O escravismo colonial. São Paulo: Ática, S/D.

GORENDER; Jacob. A escravidão reabilitada. São Paulo: Expressão Popular, 2016.

HARVEY, David. Contradições e o fim do capitalismo. São Paulo: Boitempo, 2016.

HARVEY, David. A loucura da razão econômica: Marx e o Capital no século XXI. São Paulo: Boitempo, 2018.

HOBSBAWM, Eric. Cómo cambiar el mundo. Barcelona: Critica, 2011.

IANNI; Octavio. A ditadura do grande capital. São Paulo: Expressão Popular, 2019.

JINKINGS, Ivana; DORIA, Kim; CLETO, Murilo. (orgs.). Por que gritamos golpe? Para entender o impeachment e a crise política no Brasil. São Paulo: Boitempo, 2016.

KORYBKO, Andrew. Guerras híbridas: das revoluções coloridas aos golpes. São Paulo: Expressão Popular, 2018.

LÊNINE, Vladimir I. O imperialismo, fase superior do capitalismo. Brasília: Nova Palavra, 2010 .

LENIN; Vladimir I. O estado e a revolução. São Paulo: Expressão Popular, 2007.

MALANCHEN, Julia. Cultura, conhecimento e currículo. Campinas: Autores Associados, 2016.

MANACORDA, Mario Alighiero. Diana e Le Muse: tremila anni di sport nella letteratura. Opra 4 volumi. Italia: Lancilotte e Nausica, 2016.

MARGEM ESQUERDA. Dossiê Bolsonaro. Revista da Boitempo. 31 , 1 semestre 2019.

MARTINS, Lígia Marcia. O desenvolvimento do psiquismo e a educação escolar: contribuições à luz da psicologia histórico-cultural e da pedagogia histórico-critica. Campinas: Autores Associados, 2015.

MARTINS; Lígia Márcia. O que ensinar? O patrimônio cultural humano como conteúdo de ensino e a formação da concepção de mundo no aluno. In: PAUSQUALINI, Juliana Campregher; TEIXEIRA, Lucas André; AGUDO, Marcela de Moraes. Pedagogia histórico-critica: legado e perspectivas. Uberlândia: Navegando Publicações, 2018. p. 83-98.

MARX, Karl. Contribuições à crítica da economia política. 2.ed. São Paulo: Martins Fontes, 1983. 
MARX, Karl; ENGELS, Friederich. A ideologia alemã. São Paulo: Boitempo, 2007.

MASCARENHAS, Fernando; ATHAYDE, Pedro F.; MATIAS, Wagner B. Políticas de esporte nos anos Lula e Dilma. Brasília: Thesaurus, 2015.

MASCARENHAS, Fernando. Megaeventos esportivos e educação física: alerta de tsunami. Revista Movimento, Porto Alegre/RS. v. 18, n. 1, jan./mar. 2012.

MASCARENHAS, Fernando. O estado brasileiro e os direitos sociais: o lazer. In GARCIA, Carla Cristina; HÚNGARO, E. M.; DAMASCENO, Luciano Galvão A. (Orgs.). Estado, política e emancipação humana. Santo André: Alpharrabio, 2008.

MASCARENHAS, Gilmar.; BIENENSTEIN, G.; SÁNCHEZ, F. (Orgs.). O jogo continua: megaeventos esportivos e cidades. Rio de Janeiro: UERJ, 2011.

MASCARO, Alysson Leandro. Crise e golpe. São Paulo/SP: Boitempo, 2018.

MASCARO, Alysson Leandro. Estado e forma política. São Paulo/SP: Boitempo, 2013.

MATIAS, W. B., ATHAYDE, Pedro F., MASCARENHAS, Fernando. Políticas de esportes nos anos Lula e Dilma. Brasília: Thesaurus, 2015.

MATTOS; Marcelo Badaró. Estado e formas de dominação no Brasil contemporâneo. Rio de Janeiro: Consequência Editora, 2017.

MELO, Marcelo Paula de. Esporte e juventude pobre: políticas públicas de lazer na vila olímpica da Maré. Campinas: Autores Associados, 2005.

MÉSZÀROS, István. Para além do capital. São Paulo: Boitempo, 2002.

MÉSZÀROS, István. O século XXI: socialismo ou barbárie? São Paulo: Boitempo, 2003.

MÉSZÀROS, István. O desafio e o fardo do tempo histórico. São Paulo: Boitempo ,2007.

MEZZADRI, Fernando M. Inteligência esportiva. Curitiba: UFPR, 2016.

MEZZADRI, Fernando M. Políticas públicas de esporte. Várzea Paulista: Fontoura, 2014.

MIGUEL; Luiz Felipe; BIROLI; Flávia. Feminismo e política. São Paulo: Boitempo, 2014.

MIGUEL; Luiz Felipe. Dominação e resistência. São Paulo: Boitempo, 2018.

MONTORO, Xabier Arrizabalo. Capitalismo y economia mundial. Bases teóricas y análises empíricas para la compreensión de los problemas econômicos del siglo XXI. Madrid: Instituto Marxista de Economia. Universidad de Arte Y Ciências Sociales e Universidad de Concepción, 2014.

MONTORO, Xabier Arrizabalo. Financeirização? Não, imperialismo, crescimento da exploração e crise crescente do Capital. A Verdade, n. 97, ago. 2018. 
NASCIMENTO; Abdias do. O genocídio do negro brasileiro: processo de um racismo mascarado. Rio de Janeiro: Paz e Terra, 1978.

REPPOLD FILHO, Alberto R. Megaeventos esportivos e ciências do esporte no Brasil. In:

TONDIN, Gilmar et. al. (org.) Esporte e lazer no Brasil: divisão de responsabilidades entre os entes federativos. Porto Alegre: Companhia Rio-grandense de Artes Gráficas, 2013.

REPPOLD FILHO, Alberto R. Apresentação: Jogos Olímpicos Rio de Janeiro 2016. Ciência Cultura, São Paulo, v.68, n.2, abr./jun., 2016.

REPPOLD FILHO, Alberto R. et al. Olimpismo e educação olímpica no Brasil. Porto Alegre: UFRGS, 2009.

REPPOLD FILHO, Alberto R.; DAMIANI, Cassia; FONTANA, P. Positive and negative aspects of sports mega-events in Brazil: a preliminary view. In: MATURANA-DOS-SANTOS, Leonardo J.; PENA, Bia Gama (orgs.). Mega events footprints past, present and future. Rio de Janeiro:

Engenho, 2017.

PASQUALINI, Juliana; TEIXEIRA, Lucas André; AGUDO, Marcela de Moraes (Orgs.).

Pedagogia histórico-crítica: legado e perspectivas. Uberlândia: Navegando Publicações, 2018.

NOVO, Benigno Nunes. Lawfare. In: https://jus.com.br/artigos/65311/lawfare Acesso dia 20/06/19 as $20: 48 \mathrm{~h}$.

PRASHAD, Vijay. Nas ruinas do presente. Documento de Trabalho. N. 1 Instituto Tricontinental da Pesquisa Social. Grapihum Gráfica e Editora, S/D. www.otricontinental.org

PRONER, Carol; CITTADINO, Gisele; TENENBAUM, Marcio; RAMOS FILHO; Wilson. A resistência ao golpe de 2016. Bauru/ São Paulo: Canal Editora, 2016.

RAMOS, Gustavo Teixeira; LOGUERCIO; José Eymard; MELO FILHO, Hugo Cavalcanti;

RAMOS FILHO, Wilson. O Golpe de 2016 e a reforma da previdência: narrativas e resistências. Bauru: Canal 6, 2017.

SAFFIOTI, Heleieth. A mulher na sociedade de classes: mito e realidade. São Paulo: Expressão popular.2013.

SAVIANI, Demerval; DUARTE, Newton (Org.). Pedagogia histórico-crítica e luta de classes na educação escolar. Campinas: Autores Associados, 2012.

SAVIANI, Demerval. Educação: Do senso comum à consciência filosófica. 18. ed. Campinas: Autores Associados, 2009.

SCHWARTZ, Gisele Maria. Gestão da informação sobre esporte recreativo e lazer: balanço da rede CEDES. (2010) Disponível em: http://www.cedes.ufsc.br:808 0/xmlui/handle/

123456789/287. Acesso em: 19 de junho 2019. 
SIMÕES; Roberto. A ação criminosa das ONGs: a privatização da escola pública. Rio de Janeiro: Consequência Editora, 2017.

SINASEFE- IFBA. Cadernos de feminismo sindical: notas sobre a luta das mulheres. Volume 1. Bahia, S/D.

SOUZA, Jessé. A radiografia do golpe. Entenda por que você foi enganado. Rio de Janeiro: LeYa, 2016.

SOUZA, Jessé. A elite do atraso: da escravidão à Lava Jato. Rio de Janeiro: LeYa, 2017.

SOUZA, Jessé. A tolice da inteligência brasileira. Ou como o país se deixa manipular pela elite. Rio de Janeiro: LeYa, 2015.

SOUZA, Joelson (Org.). Questão negra: a luta pela consciência negra e o combate pela revolução. São Paulo: Nova Palavra, 2019.

SIMÕES, Roberto Alves. A ação criminosa das ONGs: a privatização da escola pública. Rio de Janeiro: Consequência Editora, 2017.

TAFFAREL, Celi; ESCOBAR, Michele. Cultura corporal e os dualismos necessários à ordem do capital. 2010. Disponível em: $<$ http://www.rascunhodigital.faced.ufba.br/ver.php?idtexto=277 $>$. Acesso em: 18 maio 2019.

TAFFAREL, Celi Nelza Zulke. Esporte na escola e o esporte de rendimento: reafirmando o marxismo contra as ilusões e as imposturas, 2010. Disponível em https://fefd.ufg.br/up/73/o/Texto_102_-_Esporte_na_Escola_e_o_Esporte_de_Re ndimento_Celi_Zulke_Taffarel_.pdf Acesso em:18 maio 2019.

TEIXEIRA, David Romao; DIAS, Fernanda B. A Necessidade Histórica da cultura corporal: Limites e possibilidades sob a ordem do Capital. Motrivivencia. Ano XXIII, N. 36, Jun/ 2011, PP: 94-110.

TEIXEIRA, Marcelo Resende et al. Política social de esporte e lazer no governo Lula: o programa esporte e lazer da cidade. In: MATIAS Wagner; ATHAYDE, Pedro F; MASCARENHAS, Fernando. (orgs.). Políticas de esporte nos anos Lula e Dilma. Brasília: Thesauros, 2015.

TOMMASI, Livia de; WARDE, Mirian Jorge; HADDAD, Sérgio. O banco mundial e as políticas educacionais. São Paulo: Cortez; Ação Educativa; PUC; 1996.

TROTSKY, Leon. Programa de Transição. In: MARX, Karl; ENGELS, Friedrich; LÊNIN,

Vladimir; TROTSKY, Leon. O programa da revolução. Brasília: Nova Palavra, 2018.

TROTSKY, Leon. Como esmagar o fascismo. São Paulo/SP: Autonomia Literária, 208.

VALIM, Rafael. Estado de exceção: a forma jurídica do neoliberalismo. São Paulo:

Contracorrente, 2017. 
VERONEZ, Luiz Fernando. Quando o Estado joga a favor do privado: as políticas de esporte após a Constituição Federal de 1988. Tese (Doutorado em Educação Física). Campinas:

UNICAMP, 2005.

VERONEZ, Luiz Fernando; GANZER, Vinicius Rosa; BLANK, Priscila. O método de gestão do Ministério do Esporte. In: EFDeportes.com - Revista Digital. Buenos Aires, Ano 18, N. 179, Abril de 2013. https://www.efdeportes.com/efd179/metodo-de-gestao-do-ministerio-do-esporte.htm. Acesso em 5 de julho de 2019.

ZETKIN, Clara. Como nasce e morre o fascismo. São Paulo/ SP: Autonomia Literária: 2019.

\section{NOTA DO AUTOR}

\section{AGRADECIMENTO}

A professora Cassia Damiani pelo esforço incansável para consolidar o Sistema Nacional de Esporte (SNE) no Brasil.

\section{CONTRIBUIÇÃO DE AUTORES}

Não se aplica.

\section{FINANCIAMENTO}

CNPQ PRODUTIVIDADE PESQUISA - CELI NELZA ZULKE TAFFAREL.

\section{CONSENTIMENTO DE USO DE IMAGEM}

Não se aplica.

\section{APROVAÇÃO DE COMITÊ DE ÉTICA EM PESQUISA}

Não se aplica

\section{CONFLITO DE INTERESSES}

Não se aplica.

\section{LICENÇA DE USO}

Os autores cedem à Motrivivência - ISSN 2175-8042 os direitos exclusivos de primeira publicação, com o trabalho simultaneamente licenciado sob a Licença Creative Commons Attribution Non-Comercial ShareAlike (CC BY-NC SA) 4.0 International. Estra licença permite que terceiros remixem, adaptem e criem a partir do trabalho publicado, desde que para fins não comerciais, atribuindo o devido crédito de autoria e publicação inicial neste periódico desde que adotem a mesma licença, compartilhar igual. Os autores têm autorização para assumir contratos adicionais separadamente, para distribuição não exclusiva da versão do trabalho publicada neste periódico (ex.: publicar em repositório institucional, em site pessoal, publicar uma tradução, ou como capítulo de livro), com reconhecimento de autoria e publicação inicial neste periódico, desde que para fins não comerciais e compartilhar com a mesma licença. 


\section{PUBLISHER}

Universidade Federal de Santa Catarina. Programa de Pós-Graduação em Educação Física. LaboMídia - Laboratório e Observatório da Mídia Esportiva. Publicado no Portal de Periódicos UFSC. As ideias expressadas neste artigo são de responsabilidade de seus autores, não representando, necessariamente, a opinião dos editores ou da universidade.

\section{EDITORES}

Mauricio Roberto da Silva, Giovani De Lorenzi Pires, Rogério Santos Pereira.

\section{HISTÓRICO}

Recebido em: 05 de julho de 2019.

Aprovado em: 17 de setembro de 2019. 